症例

\title{
黄瘟を主訴として来院した301症例の検討
}

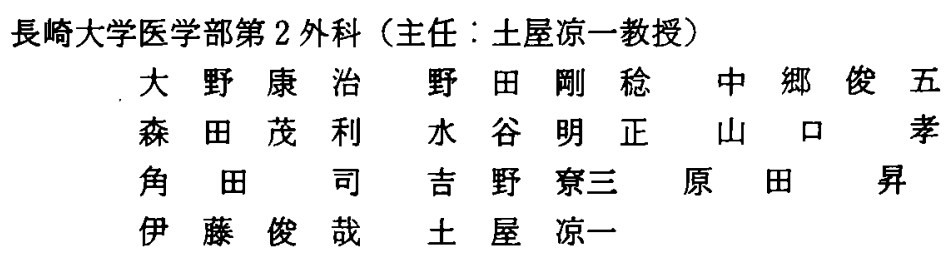

\section{STUDY OF 301 JAUNDICED PATIENTS}

Yasuharu OHNO, Takatoshi NODA, Syungo NAKAGO, Shigetoshi MORITA, Meisei MIZUTANI, Takashi YAMAGUCHI, Tsukasa TSUNODA, Ryozo YOSHINO, Noboru HARADA, Toshiya ITO and Ryoichi TSUCHIYA

Second Department of Surgery, Nagasaki University School of Medicine (Director : Prof. Ryoichi Thuchiya)

最近の各種画像䛦断法の進歩はめざましく，黄疾症例に対する質的診断の過程に大き な変遷をむたらした，我々は過去12年間に経験した黄疸症例を分析し，これらに用いら れた各種画像診断法を評価することによって，その合理的な使用法について考察した。

昭和44年10月より昭和56年12月までに黄疸を主訴として来院した症例は301例であり， この5ち，悪性疾患が170例と過半数を占め，良性疾患は129例，確定猃断不詳なものは 2 例であった。悪性疾患の中では胆管癌が 63 例と最も多く，以下，满癌，胆变癌，肝細 胞癌, 膨大部癌の順であった。一方，良性疾患では胆石症が83例を占め，良・悪性を通 して最多であった。

各種検查の施行頻度をみると, PTC が163例と最も多く施行され, 以下, Angio., US, ERCP，CT，DIC の順であった. PTC と Angio.は悪性疾患に多く用いられており，一方， US, ERCP は良性疾患に多く用いられていた。

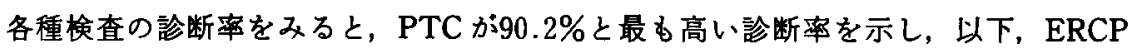
$75.5 \%$, CT 74.5\%, US 64.6\%, Angio. 63.2\%, DIC 28.6\%, の順であった。悪性疾患に おいては，PTC，ERCPなどの侵裝的検查の診断率が高かった。一方，良性疾患におい ては，PTC，ERCPなどとともに非侵輩的検査であるCT す良好な成積を示していた。

DICはその施行率, 診断率ともに低率であった. US は急速に普及し, 近年はほ全黄疸 症例に対して施行されているが，䐙癌・膨大部癌・胆尧癌などで低い診断率を示した。 CT は各疾患を通して平均した診断率を示したことが特徽であった. ERCPは胆道・愺臓 垁患に対して特に有効であった，PTCは良性・悪性を通して最も良い成績を示した。 Angio.は胆管癌・膨大部癌では低い診断率を示した。

以上，黄疸の原因知患とその検査法について検討した。

事引用語：黄疸, 画像診断

腥

消化器疾患を扱ら施設では黄㾝を主訴として来院す る患者は多く、これらに対する処置も䅫急を要するこ
とが多いそそのため黄㾞の原因あるいは質的診断を早 く正しく行ならことが常に要求される.

最近の消化器疾患領域における各種画像診断法の進 
歩はめざましく，従来施行されてきた胆熦造影法 (DIC), 内視鏡的逆行性胆道堙管造影法 (ERCP), 䅅皮 経肝胆道造影法 (PTC) 兼胆道ドレナージ術 (PTCD), 血管造影法 (Angiography) などの諸検查も種々の改 良が加えられ, 更にComputed Tomography (CT), 腹 部超音波検查法 (US) などの非侵㜔的検查も多用され るようになってきている。

今回の目的は当教室で約12年間に経験した黄疾症例 を分析し，各種疾患の病態を明らかにするとともに， 診断に用いられたこれらの各種画像診断法を評価し， 黄疾を主訴とする患者に対する検査法の合理的な使用 法を確立することにある。

\section{対象}

昭和44年10月上り昭和56年12月までに黄疸を主訴と して長崎大学第 2 外科に来院した症例（血清総ビリル ビンが $2.0 \mathrm{mg} / \mathrm{dl}$ 以上のるの）は表 1 に示すごとく総 数301例であった．5ち男性は170例(56.5\%)，女性は 131 例(43.5\%)であり，平均年齡はそれぞれ $59.0 \pm 12.3$ 歳, $58.1 \pm 12.5$ 歳であった。

手術・剖検および臨床経過で悪性と診断されたもの は170例 (56.5\%) で全症例の過半数を占め, 良性例は 129 例 (42.9\%), 確定診断が不詳なものは 2 例であっ た。

疾患の内訳は表 2 に示すごとく，悪性疾患170例の5 ちでは胆管癌が63例と最も多く，全症例の $20.9 \%$ 占 めた，以下，满癌48例 $(15.9 \%)$ ，胆襄癌 26 例 $(8.6 \%)$, 肝細胞癌 16 例 (5.3\%)，膨大部癌 8 例 (2.7\%)，その 他 9 例 (2.9\%) であった。一方, 良性疾患では胆石症 が83例と全症例の $27.6 \%$ 占め, 今回の対象例の中で は良性・悪性を通して最も多かった（胆囊結石17例， 総胆管結石 48例, 肝内結石18例). 以下, 良性肝疾患21 例 $(7.0 \%)$ ，良性胆道疾患19例 $(6.3 \%)$, 慢性脺炎 5 例 $(1.7 \%)$ ，その他 1 例 $(0.03 \%)$ であった。

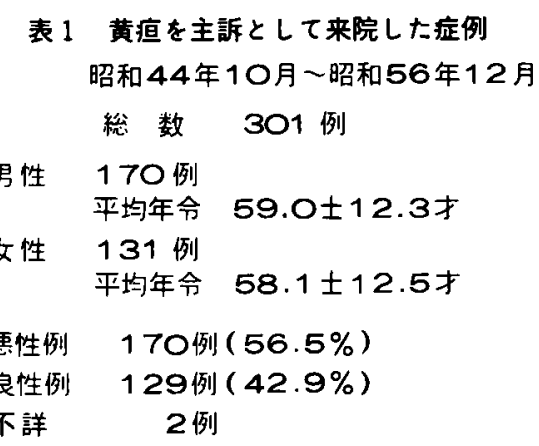

\section{表 2 疾患の内訳}

要性疾患

\begin{tabular}{|c|c|}
\hline 胆 管 㾞 & 63 例 ( $20.9 \%)$ \\
\hline 膵 酒 & 48 例 (15.9\%) \\
\hline 胆 責在 & 26 列 $(8.6 \%)$ \\
\hline 肝細胞病 & 16 例 ( $5.3 \%)$ \\
\hline 大部㾂 & 8 例 ( $2.7 \%)$ \\
\hline の他 & 9 例 $(3.0 \%)$ \\
\hline
\end{tabular}

良性矣患

$\begin{array}{lr}\text { 胆石症 } & 83 \text { 例 }(27.6 \%) \\ \text { 良性肝疾患 } & 21 \text { 例 }(7.0 \%) \\ \text { 良性胆道疾患 } & 19 \text { 例 }(6.3 \%) \\ \text { 憬性膵炎 } & 5 \text { 例 }(1.7 \%) \\ \text { その他 } & 11 \text { 例 }(0.3 \%)\end{array}$

表 3 各程梌查施行頻度

\begin{tabular}{|c|c|c|c|c|c|c|c|c|}
\hline & & & DIC & US & CT & ERCP & PTC & Angio \\
\hline \multirow{6}{*}{$\begin{array}{l}\text { 㤟 } \\
\text { 性 } \\
\text { 疾 } \\
\text { e }\end{array}$} & 胆需和 & 63刑 & 3 & 19 & 7 & 16 & 54 & 39 \\
\hline & 榉 & 48 列 & 5 & 10 & 11 & 11 & 36 & 32 \\
\hline & 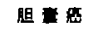 & 26 刑 & 4 & 6 & 6 & 6 & 22 & 13 \\
\hline & 肝 & 16 所 & $\mathbf{3}$ & 5 & 5 & 1 & 3 & 13 \\
\hline & 站大部品 & 8 列 & 1 & 2 & 4 & 7 & 6 & 8 \\
\hline & その地 & 9 列 & 2 & 5 & 1 & 2 & 4 & 3 \\
\hline & int & & 18 & 47 & 33 & 43 & 125 & 108 \\
\hline \multirow{5}{*}{$\begin{array}{l}\text { 是 } \\
\text { 性 } \\
\text { 疾 }\end{array}$} & 胆石泣 & 83 列 & 28 & 36 & 12 & 35 & 32 & 14 \\
\hline & 艮泩訮疾。 & 21 列 & 2 & 8 & 4 & 9 & 2 & 8 \\
\hline & 良住胆道洗 & 19列 & $\mathbf{3}$ & 7 & 4 & 4 & 2 & 5 \\
\hline & 经珄资 & 6 列 & 6 & 1 & 1 & 3 & 2 & 1 \\
\hline & その他 & 1 列 & 0 & o & 1 & 0 & o & 0 \\
\hline & it & & 38 & 52 & 22 & 51 & 38 & 28 \\
\hline & \& 8 & & 56 & 99 & 55 & 94 & 163 & 136 \\
\hline
\end{tabular}

以下はこれらの疾患に対して用いられた各種画像診 断法の評価について述べる. 各種検査の判定にあたっ ては，その基準を抽ことが必要となる，我々は黄疸 の原因疾患の同定を行ならに足る所見を呈しているか 否かを判定基準とし，例えは，肝内胆管の昖張がみら れても，原因疾患の同定を行な5に足る所見がない場 合は陰性とし，また，造影不良例あるいは失敗例など す全て陰性として扱った。

\section{結 果}

表 3は各種検查施行頻度を示している．各種検查の ちちでは，PTCが163例と最も多く施行され，以下， Angio. 136例, US 99例, ERCP 94例, CT 55例, DIC 54例の順であった。 PTCは悪性疾患170例中125例 (73.5\%)，良性疾患129例中38例(29.5\%)に施行され， また Angio. 。悪性 108例 (63.5\%)，良性28例 (21.7\%) と，いずれも悪性疾患に多く用いられていた。これた 対し，US は悪性47例 (27.6\%)，良性52例 (40.3\%)， ERCPはそれぞれ35例 (20.5\%)，51例 (39.5\%) と， 
表 4 黄疸症例における各種模査診断率

\begin{tabular}{|c|c|c|c|c|c|}
\hline D I C & U S & C T & E R P & P T C & Angio \\
\hline $28.6 \%$ & $64.6 \%$ & $74.5 \%$ & $75.5 \%$ & $90.2 \%$ & $63.2 \%$ \\
$(16 / 56)$ & $(64 / 99)$ & $(41 / 56)$ & $(71 / 94)$ & $(147 / 163)$ & $(86 / 136)$ \\
\hline
\end{tabular}

表 5 悪性疾患における各種検查診断率

\begin{tabular}{|c|c|c|c|c|c|c|}
\hline & $D I C$ & US & C T & ERCP & PTC & Angio \\
\hline 地 & $(O \%)$ & $\begin{array}{r}68.4 \% \\
(13 / 19)\end{array}$ & $\begin{array}{l}57.1 \% \\
(4 / 7)\end{array}$ & $\begin{array}{c}87.6 \% \\
(14 / 16)\end{array}$ & $\begin{array}{c}88.9 \% \\
(48 / 54)\end{array}$ & $\begin{array}{c}36.9 \% \\
(14 / 39)\end{array}$ \\
\hline w & $(0 \%)$ & $(40 \%)$ & $\begin{array}{l}63.6 \% \\
(7 / 11)\end{array}$ & $\begin{array}{l}81.8 \% \\
(9 / 41)\end{array}$ & $\begin{array}{c}94.4 \% \\
(34 / 36)\end{array}$ & $\begin{array}{c}90.6 \% \\
(29 / 32)\end{array}$ \\
\hline 柦 $=1$ & $\begin{array}{l}26 \% \\
(1 / 4)\end{array}$ & $\begin{array}{l}33.3 \% \\
(2 / 6)\end{array}$ & $(4 / 6)$ & $\begin{array}{c}60 \% \\
(3 / 6)\end{array}$ & $\begin{array}{c}96.6 \% \\
(21 / 22)\end{array}$ & $\begin{array}{c}76.9 \% \\
(10 / 13)\end{array}$ \\
\hline 保 & $(\alpha / 3)$ & $\begin{array}{l}100 \% \\
(6 / 6)\end{array}$ & $\begin{array}{l}100 \% \\
(5 / 5)\end{array}$ & (O\% & $\begin{array}{l}100 \% \\
(3 / 3)\end{array}$ & $\begin{array}{r}92.3 \% \\
(12 / 13)\end{array}$ \\
\hline E大部态 & $(0 \%)$ & $\left(\begin{array}{l}60 \% \\
(1 / 2)\end{array}\right.$ & $(35 \%)$ & $100 \%$ & $\begin{array}{l}100 \% \\
(6 / 6)\end{array}$ & $\begin{array}{l}62.6 \% \\
(5 / 8)\end{array}$ \\
\hline モの地 & $(O \% / 2)$ & $\begin{array}{c}60 \% \\
(3 / 6)\end{array}$ & $(0 \%)$ & $(0 \%)$ & $(2 / 4)$ & $\begin{array}{l}6 \in \cdot 7 \% \\
(2 / 3)\end{array}$ \\
\hline & $\begin{array}{c}5.6 \% \\
(1 / 18)\end{array}$ & $\begin{array}{r}69.6 \% \\
(28 / 47)\end{array}$ & $\begin{array}{r}69.7 \% \\
(23 / 33)\end{array}$ & $\begin{array}{c}76.7 \% \\
(33 / 43)\end{array}$ & $\begin{array}{c}91.2 \% \\
(114 / 126)\end{array}$ & $\begin{array}{c}66.7 \% \\
(72 \mu)\end{array}$ \\
\hline
\end{tabular}

いずれる良性疾患に多く用いられていた。

全体としての各種検査診断率をみると、表 4 のごと く, PTC が163例中147例 $(90.2 \%)$ 上最も高い診断率 を示し，以下， ERCP 75.5\%, CT 74.5\%, US 64.6\%, Angio. 63.2\%, DIC 28.6\%の順であった.

これを悪性疾患についてみると，表 5 に示すごとく， PTC が125例中114例 (91.2\%) と最も高い診断率を示 し, 以下, ERCP 76.7\%, CT 69.7\%, Angio. 66.7\%, US 59.6\%の順であり, DIC はわずか $5.6 \%$ あった。 全症例に占めるのと同様に，悪性疾患においてる PTC, ERCPなどの侵龍的検查の診断率が高かった。

胆管癌での診断率は, PTC が88.9\%, ERCP が 87.5\%といずれも高率を示し, 以下, US, CT, Angio., DICの順であり， Angio.はわずか35.9\%であった。

腪癌においては，PTCが94.4\%，Angio.が90.6\%， ERCP かi81.8\%と高率を示し, 以下, CT, US, DICの 順であり，US はわずか40\%であった。

胆要癌においては，PTCが95.5\%と高率であり，以 下, CT, Angio., ERCP, US, DIC の順であり, ERCP は50\%,USは33.3\%であった。

肝細胞癌の場合，US，CT，PTCがいずれる100\%， Angio. が92.3\%と高率を示した。

膨大部癌の場合, ERCP, PTCが100\%と高率であ ク, 以下, CT, Angio., US, DIC の順であった。

一方, 良性疾患においての各種検査診断率をみると， 表 6 に示すごとく，PTCが38例中33例（86.8\%）と最
表 6 良性疾患における各程模査診断嘸

\begin{tabular}{|c|c|c|c|c|c|c|}
\hline & $\mathrm{D} I \mathrm{C}$ & us & C T & ERCP & P T C & Angio \\
\hline 胆石肯 & $\begin{array}{c}53.6 \% \\
(15 / 28)\end{array}$ & $\begin{array}{c}75 \% \\
(27 / 36)\end{array}$ & $\begin{array}{c}75 \% \\
(9 / 12)\end{array}$ & $\begin{array}{c}80 \% \\
(28 / 36)\end{array}$ & $\begin{array}{c}84,4 \% \\
(27 / 32)\end{array}$ & $21 ; 4 \%$ \\
\hline 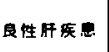 & $(0 \%)$ & $\begin{array}{l}87.6 \% \\
(7 / 8)\end{array}$ & $\begin{array}{l}100 \% \\
(4 / 4)\end{array}$ & $\begin{array}{l}77.8 \% \\
(7 / 9)\end{array}$ & $\begin{array}{l}100 \% \\
(2 / 2)\end{array}$ & $\begin{array}{l}100 \% \\
(B / 8)\end{array}$ \\
\hline 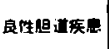 & $\begin{array}{l}33.3 \% \\
(1 / 3)\end{array}$ & $\begin{array}{l}28.6 \% \\
(2 / 7)\end{array}$ & $(35 \%)$ & $(1 / 4)$ & $100 \%$ & $\begin{array}{c}40 \% \\
(2 / 6)\end{array}$ \\
\hline 性雨炎 & $\left(\begin{array}{l}O \% \\
(0 / 5)\end{array}\right.$ & $\begin{array}{l}0 \% \\
(0 / 1)\end{array}$ & $\begin{array}{l}100 \% \\
(1 / 1)\end{array}$ & $\begin{array}{l}66.7 \% \\
(2 / 3)\end{array}$ & $\begin{array}{l}100 \% \\
(2 / 2)\end{array}$ & $\begin{array}{l}100 \% \\
(1 / 4)\end{array}$ \\
\hline$€$ の他 & $(a / 0)$ & $(0 / 0)$ & $\begin{array}{l}100 \% \\
(1 / 1)\end{array}$ & $(O / O)$ & $(\alpha)$ & $(0 / 0)$ \\
\hline & $\begin{array}{c}42.1 \% \\
(16 / 38)\end{array}$ & $\begin{array}{c}69.2 \% \\
(36 / 52)\end{array}$ & $\begin{array}{c}81.8 \% \\
(18 / 22)\end{array}$ & $\begin{array}{r}74.6 \% \\
(38 / 61)\end{array}$ & $\begin{array}{c}86.8 \% \\
(33 / 38)\end{array}$ & $\begin{array}{c}50 \% \\
(14 / 28)\end{array}$ \\
\hline
\end{tabular}

高率を示し，以下，CT $81.8 \%$, ERCP $74.5 \%$, US 69.2\%, Angio. 50\%, DIC 41.7\%の順であった.

胆石症においては，PTCか $84.4 \%$ と高率であり，以 下, ERCP, US, CT, DIC, Angio.の順であった.

良性肝疾患にお゙いては，CT，PTC，Angioかがずれ も100\%と高率であり，以下，US, ERCP, DIC の順で あった。

良性胆道垁患においては，PTCが100\%であり，以 下, CT, Angio., DIC, US, ERCP の順であった.

慢性羘炎の場合, CT, PTC, Angio.が100\% と高率を 示し, 以下, ERCP, DIC, US の順であった。

\section{考察}

黄㡺を主訴とする症例においては，一般に，その原 因が悪性腫惕によることが多(、1) 99. 自験例も例外で なく，301例中 170 例 $(56.5 \%$ ）と悪性属場によるもの が過半数を占めた。悪性疾患の中では胆管癌が63例と 全体の $20.9 \%$ を占め, 次いで莁癌 $15.9 \%$, 胆素癌 $8.6 \%$, 肝細胞癌 $5.3 \%$ ，膨大部癌 $2.7 \%$ の順であった。しかし， 疾患別にみると胆石症が83例と最も多く，全体の $27.8 \%$ を占めていたことは特徵的であった。

一方, 検查についてみると，まず DIC は黄疸の存在 のもとでは一般にその診断率は低く，総ビリルビン値 $4 \mathrm{mg} / \mathrm{dl}$ 以上の症例では造影不可能であるといわれて おり，その施行例は減少しつつあるのが実情である。 自験例でもその施行率は $17.9 \%$ と低く，また猃断率も $29.6 \%$ と低かった。しかし，胆石症に関しては $53.4 \%$ の診断率を示していた。

USはその機器の発展がめざましく，また，患者に対 する侵䘫が少なく繰り返し施行できることもあり，急 速に普及し近年ほぼ全㾞症例に対して施行されてお。 ク， 64.6\%の診断率を示している，较癌・膨大部癌・ 胆菜癌などで低率であることが問題であるが，これは， 機器の発展とともに, 腸管ガス像の排除, 体位の工夫 
などが徽底すれば更に診断率は向上するすのと思われ る.

黄疸症例の診断過程における US の最大の特微は,

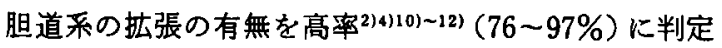
できることである。これは，閉塞性黄疸と肝細胞性黄

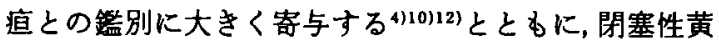
疸に打ける閉塞部位の診断にむ役立ち(16)10) (58 86\%)，以後の検查および治療の指標にも充分に なりらることを示唆している。

CT 74.5\%と良好な診断率を示し, US とともに非 侵襲的検查の双壁をなしている，USに比べその機動 性の低いことが弱点であるが，悪性良性を問わず各疾 患を通して平均した診断率を示し, 閉塞部位の検索に

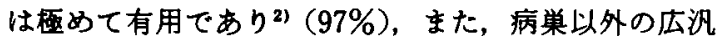
な情報を収集でき，手術指針の一助となりらることが 特徽である。

ERCP は諸家の報告13)599では55９1\%の診断率を 示し，特に下部胆管系に異常の存在するときに有用で あるとされている゙．自験例においても75.5\%と良好

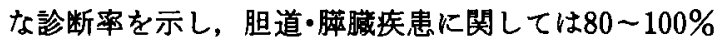
と高率であることが特微であった。しかし，訮外閉塞 例においては, supprative cholangitis が発生しやすい との報告もあり ${ }^{113)}$ ，USを指磦とし中等度から高度の 胆道系の抾張を有する症例では，ERCPよりすPTC を先に施行する方が，減黄をはかる意味からる， cholangitisを防ぐ意味からる有奻であると考えられ る.

PTC は諸家の報告13) 6)9/11)では37～94\%の診断率 をあげている，自験例においては，最も多く施行され た検查であり，特に悪性疾患では170例中125例 (73.5\%)に施行されており，また，90.2\%と今回最も 良好な診断率を示し，各疾患に対して平均して高率な 結果をあげている，PTCの最大の特微は，これが診断 的手技であるとともに，ドレナージを併用することに 上る治療的側面も持っていることである，减黄を期待 できる点, cholangitis を予防・鎮静化できる点からす， 高度閉塞性黄㡺患者の術前状態の改善, poor-risk surgical patients, inoperable patientsに対する palliative therapy としても欠かすことはできないもので ある．特にUS を補助手段として併用するようになっ た最近では，穿刺回数も减少し，出血や胆汁漏出等の 合併症も非常に少なくなってきている.

Angiography は63.2\%の診断率であった。これは胆 管癌・膨大部癌における診断の困難さを反映している.

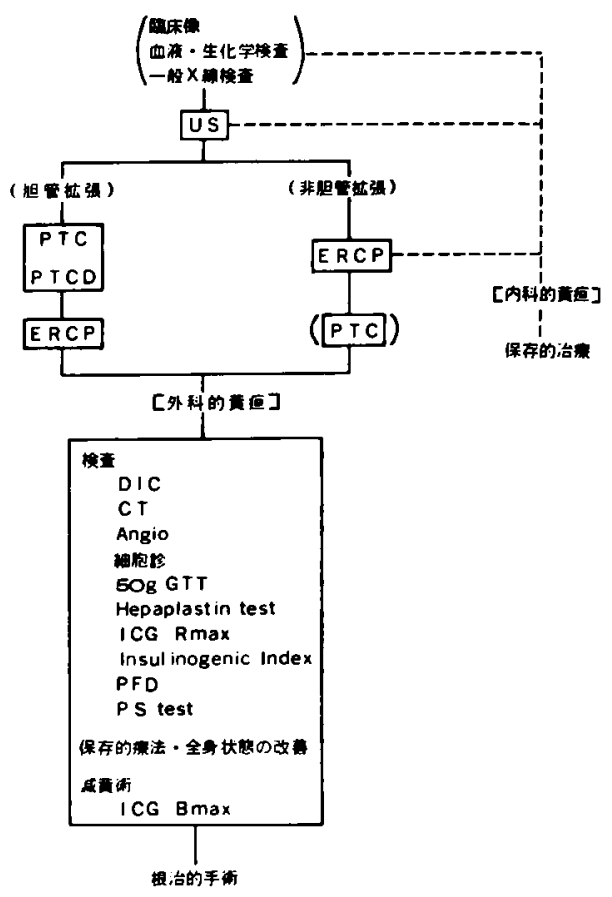

图 1 黄㾝症例に対する Diagnostic Flow Chart

これらは，一般に血管陰影に乏しく特徽的な変化を示 すことが少ないためであると考えられ，この領域にお ける今後の工夫が期待される. 現在, 各種両像診断法 の進歩により Angio. のみで診断可能な症例は稀であ ク，その診断的価値は减少している，むしろ，病巣の 正確な把握，局所進展の状况・他甈器転移の有無の診 断など，手術適応の有無・手術方法の選択に関して重 要な意味を持つといえる。

以上，黄㡺の原因となった疾患と，その診断に用い られた各種画像診断法について検討した，黄㡺患者が 来院した場合，その処置は緊急を要することが多く， 纽速で的確な診断が必要であり，また，それに用いら れる検查は，無䭾がなく治療に直結したものでなくて はならない，我々は以上のことを考慮しながら諸検査 を評価することによって，手術に至るまでの Diagnostic flow chart ${ }^{317)}$ を作成した（国 1).

黄病症例が来院した場合，一般臨床検查に引き繶い てまず行なうべき検查はUSである，USにより，閉塞 性黄疾と肝細胞性黄疾とを高率に鑑別することができ る. 閉塞性黄庭例に対してはPTCD で減黄をはかり， また, 非閉塞性黄瘨例で外科的黄疸の疑われるるのに 対しては ERCPを施行し，諸検查を進めていく，病巣 の正確な把握, 病因の究明, 転移の有無などとともに, 
肝機能・堙機能なども検索し，必要があれば全身状態 の改善をはかり，根治手術へと持っていく，我々は， 閉塞性黄痛例で減黄術を施行した症例に対しては ICG Bmax を施行し，二期手術の時期・肝機能回復度 の判定の指標としている(1)15).

$$
\text { 結 語 }
$$

当教室において約12年間に経験した黄疸症例を分析 し，各垁患とそれに用いられた画像診断法を評価する とともに, 黄疸症例に対する Diagnostic flow chart 作成し，文献的考察を加えて報告した。

\section{文献}

1) Satake, K., Cho, K., Tatsumi, S., et al.: Evaluation of cholangiographic procedures in diagnosis of obstructive jaundice. Am. Surg., $47: 387-392,1981$

2) Cesar, S., Casanova, R. and Rodriguez, R. Computed tomography in obstructive jaundice. Radiology, 139 : 627-634, 1981.

3) Ginestal-Cruz, A., Pinto-Correia, J., Camilo, E., et al. : Combined approach to the differential diagnosis of cholestatic jaundice with endoscopic retrograde cholangiopancreatography, percutaneous transhepatic cholangiography, ultrasonography, and liver biopsy. Gastrointest. Radiol., 6 : 177-183, 1981.

4) Wild, S.R., Cruikshank, J.G., Fraser, G.M., et al.: Grey-scale ultrasonography and percutaneous transhepatic cholangiography in biliary tract disease. Br. Med. J., 281: 1524 $-1526,1980$.

5) Matzen, P., Malchow-M $\phi$ ller, A., Lejerstofte, J., et al.: Endoscopic retrograde cholangiopancreatography and transhepatic cholangiography in patients with suspected ob- structive jaundice. Scand. J. Gastroenterol., 17 : 731-735, 1982.

6) Vas, W. and Salem, S.: Accuracy of sonography and transhepatic cholangiography in obstructive jaundice. J. Can. Assoc. Radiol., 32 : 111-113, 1981.

7）浅野栄一, 清水康一, 太田哲生他：閉塞性黄㡺の画 像訅断, 腹部画像診断, $2: 451-460,1982$.

8) Smith, L.: Obstruction of the bile duct. Br. J. Surg., $66:$ : 69-79, 1979.

9) Matzen, P., Haubek, A., Holstchristensen, J., et al.: Accuracy of direct cholangiography by endoscopic or transhepatic route in jaundice -A prospective study. Gastroenterology, 81 : 237-241, 1981.

10) Lukes, P.J., Wihed, A. and Almersjo, O.: Ultrasound in the differential diagnosis of jaundice. Acta Radiol., 22 : 25-29, 1981.

11) Bruce, H.: Percutaneous transhepatic cholangiography: Its role in the diagnosis and treatment of the jaundiced patient. J. Am. Osteopath. Assoc., 81 : 177-182, 1981.

12) Goldberg, H.I., Filly, R.A., Korobkin, M., et al. : Capability of CT body scanning and ultrasonography to demonstrate the status of the biliary ductal system in patients with jaundice. Radiology, 129 : 731-737, 1978.

13) Datta, P.K.: The diagnosis of obstructive jaundice. Practitioner., 225 : 1803-1806, 1981.

14）井沢邦英, 岡 進, 天野力太他：胆计中 ICG 測 定に上る閉塞性黄原減黄勃後の訮機能回復度判 定. 肝贜, $21 ： 347-000,1980$.

15）岡進：閉塞性黄㡺における減黄奻果判定指標 としての胆计中 ICG 瀑度測定について，日外会 誌, 83：1307-1320， 1982. 